\title{
Environmental filters structure plant communities in the Brazilian Chaco
}

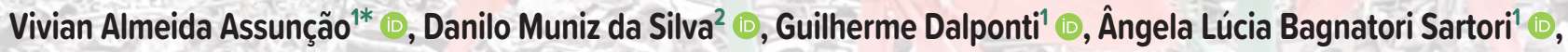 \\ José Carlos Casagrande 3 (D) and Vidal de Freitas Mansano 4 (i)
}

Received: May 1, 2020

Accepted: August 21, 2020

\begin{abstract}
We characterized taxonomic and functional differences between two vegetation physiognomies in the Brazilian Chaco, namely chaco woodland (CW) and chaco forest (CF), in order to understand which abiotic and biotic mechanisms underlie the establishment of different physiognomies. We characterized the vegetation physiognomies by comparing woody species composition, richness and diversity and functional diversity between CW and CF plots. We also measured soil variables to characterize abiotic factors related to the different physiognomies. Species richness and diversity and soil nutrient values were higher in CF. Leaf succulence and nitrogen content were higher in CW, while height, leaf area, and specific leaf area were higher in CF. The standardized effect size (SES) of functional richness was higher in CW, but the SES of functional dispersion did not differ between CF and CW. We observed a diversity gradient related to soil fertility. Traits of species in CW were related to adaptations to poor soils, while in CF floristic composition showed a prevalence of species with more attributes related to competition for light. Thus, the structure of the floristic community in CW is likely related to an environmental filter, while competition for resources prevails in $\mathrm{CF}$.
\end{abstract}

Keywords: diversity, functional traits, seasonally dry forests, plant community, physiognomy, soil fertility

\section{Introduction}

Environmental conditions and biological interactions shape community structure and pose selection pressure on species' morphological and physiological traits (Vellend 2010). Deterministic factors, such as differences in niche optimum and idiosyncratic responses to environmental seasonality, may drive species coexistence (Diamond 1975; Tang \& Zhou 2011); also, stochastic demography and dispersal may play key roles in community assembly, allowing the coexistence of species with highly overlapping niches (Connor \& Simberloff 1979; Leibold 2008). Disentangling deterministic and stochastic effects on community structuring, therefore, remains an intriguing question in plant ecology.

Physiological filters are the factors that exert selection pressure upon physiological traits that enable species to reproduce, germinate, grow, survive and establish in an environment (Lambers et al. 2008). When intolerance to environmental conditions makes it impossible for species to establish, it can be inferred that a physiological filter is constraining the community (Kraft et al. 2014). Environmental filters tend to group together species with similar traits regarding their tolerance to abiotic conditions (Pausas \& Verdú 2008). On the other hand, biological factors, such as competition and facilitation, have a wider range of effects on species composition and functional

1 Instituto de Biociências, Universidade Federal de Mato Grosso do Sul, 79070-900, Campo Grande, MS, Brazil

2 Departamento de Ciências Ambientais, Universidade Federal de São Carlos, 13565-905, São Carlos, São Paulo, Brazil

3 Universidade Federal de São Carlos, Centro de Ciências Agrárias, Departamento de Recursos Naturais e Proteção Ambiental,

13600-970, Araras, SP, Brazil

4 Instituto de Pesquisas Jardim Botânico do Rio de Janeiro, 22460-030, Rio de Janeiro, RJ, Brazil

* Corresponding author: vivian.bios@gmail.com 
differences, usually leading to trait overdispersion (Schluter 2000; Gurevitch et al. 2009; Kraft et al. 2014).

Competition tends to limit ecological similarity of cooccurring species since it is stronger among species that share functional traits and have similar ecological niches (Leibold 1998; Townsend et al. 2006). According to Loreau (2000), light differs from other resources because it is directional and, hence, generates asymmetrical interspecific competition. However, under harsh environmental conditions, fitness differences are related to specific traits; as results, competitive exclusion could hinder the establishment of species which do not present optimal adaptations and, therefore, lead to a more similar community, e.g., CAM metabolism in deserts (Kraft et al. 2014). In contrast, facilitation effects tend to allow the coexistence of species with divergent traits. In such a regime, a given species modifies environmental conditions, facilitating other species establishment (Bertness \& Callaway 1994).

Several filters within the soil and climatic conditions may occur simultaneously (Almeida et al. 2018; Pinho et al. 2019; Arruda et al. 2020), and their interaction may form ecological gradients (Whittaker 1967; Dwyer \& Laughlin 2017). The differences in environmental conditions may favor or hinder the establishment of species at un-matching degrees, therefore structuring taxonomic and functional diversity. For example, in the Chaco region, the specific composition varies spatially according to environmental conditions (Nunes 2006; Padilha 2011; Carvalho \& Sartori 2014, Morales et al. 2019). According to Ramella \& Spichiger (1989), the domain is the result of the Andes orogenic fossa that emerged at the end of the Tertiary period, and the current vegetation has been impacted by changes in climate, water and geomorphology, together with alluvial and tectonic processes, factors that likely favored the presence of many endemic species. The main ecological gradients of Chaco occur from east to west, including topography, soil types, rainfall, climate and luminosity, all interacting as filters in this formation (Morello 1967; Kunst et al. 2006). In addition, fire events and human use interfere with vegetation growth (Kunst et al. 2006).

The Chaco occurs in South America, extending through Argentina, Bolivia, Paraguay and Brazil, occupying an area of approximately $1,000,000 \mathrm{~km}^{2}$ (Ramella \& Spichiger 1989). The smallest portion is in Brazil, with about 12,145 km² (MP Silva unpubl. res.). Precipitation contributes to deferring the domain in wet and dry Chaco (Adamoli et al. 1990; Prado 1993; Morales et al. 2019). The Chaco, included in seasonal dry forest, is the most distinct vegetation formation when compared with other South American physiognomies and comprises the chaco forests and peripheral chaco seasonal forest (details in Oliveira-Filho et al. 2006). In addition, studies in Paraguay and Argentina point out that soil attributes, such as salinity, texture and drainage, contribute to the formation of landscapes and the distinction of phytophysiognomies (Lewis et al. 1990;
Navarro et al. 2006). The vegetation classification is different for each country, which makes it challenging to understand the domain as a whole. For example, in other countries usually the phytophysiognomic classification is based on the most common species (Hueck 1972). In Brazil, there is the Carandazal, in which the most common species is Copernicia alba Morong. In the official Brazilian organization, the classification depends on vegetation stratus prevalence and composition (IBGE 2012). In this case, Carandazal has the official name "Stepic Park Savanna" (BRASIL 1982; IBGE 2012).

With this aim we evaluated two of the most common Chaco phytophysiognomies with a higher number of woody individuals, chaco woodland and chaco forest (IBGE 2012). Within these habitat types, vegetation is related to soil characteristics (Nunes 2006; Sartori 2012). Accordingly, chaco woodland occurs in areas with less fertile soils; in contrast, chaco forest occurs in more fertile soils (Padilha 2011; Lima 2012). Luminosity is important, too, because it affects the structuring of assemblages in microhabitats (Leigh Jr et al. 2004). Also, because these Chaco types differ in plant height and canopy closure, the light intensity may affect the tendency of plants to establish in these chaco communities (Hueck 1972; Aerts 1999; Coomes \& Grubb 2000; Kunst et al. 2006), favoring species adapted to light competition in the forest physiognomy. Thus, chaco woodland is expected to have higher functional convergence resulting from the strength of the environmental filter, while chaco forest is expected to have higher functional divergence based on the strength of competition for light. On a local scale, it is possible to observe differences in leaf traits, for example, when luminosity varies between gradients (Vendramini et al. 2002).

Whittaker (1967) points out that there are different combinations of species along gradients, recognized as community types by ecologists, and these community types are related to environmental characteristics. The goal of this study was to verify if there is a luminosity and soil nutritional gradient associated with the chaco forest and woodland. Under these circumstances, we expected to find different species composition of woody plants according to soil factors and, by inference of analyzed traits, that luminosity for each phytophysiognomy would be different. We expected to find lower values of species diversity and richness in chaco woodland and higher values of functional diversity in the chaco forest.

\section{Materials and methods}

\section{Study areas}

Two macro-units form the Chaco: humid Chaco (more than $1200 \mathrm{~mm}$ of rainfall) and dry Chaco (500-700 mm), which present distinct vegetation according to their rainfall regime (Adamoli et al. 1990; Prado 1993). A humid portion of 


\section{Vivian Almeida Assunção, Danilo Muniz da Silva, Guilherme Dalponti, Ângela Lúcia Bagnatori Sartori, José Carlos Casagrande and Vidal de Freitas Mansano}

the Chaco is in Porto Murtinho in the state of Mato Grosso do Sul, Brazil, and contains $70 \%$ of Chaco species (Prado 1993).

Our experiment was carried out at two sites: Retiro Conceição ranch ( $21^{\circ} 41^{\prime} 07^{\prime \prime}$ S; 57046.7'16” W), comprising

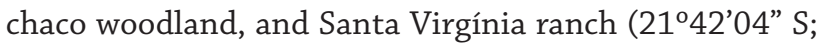
$57^{\circ} 53^{\prime} 06^{\prime \prime} \mathrm{W}$ ), comprising chaco forest. Both sites are within the municipality of Porto Murtinho. The climate is warm and dry, classified as Aw (Köppen 1948).

The soil is classified as typical Natraqualf (fine-loamy, mixed, active, isomesic), saline, and compacted, with slow drainage, which usually results in temporary flooding (BRASIL 1982). However, fertility varies according to the phytophysiognomy, partly due to litter deposition. Chaco woodland is classified as a thorny forest because the species with thorny appendices are predominant and the vegetation cover is characterized by dense understory with shrubs and a herbaceous layer followed by a low-representative canopy measuring from 3 to $15 \mathrm{~m}$ in height (UNESCO 1973). Chaco forest is a semi-deciduous montane, or cloud forest, with tropical areas in it northern and low land distribution and sub-tropical areas in its southern and higher altitude regions, with the canopy composed of tall trees, such as Ceiba spp.

The understory consists of saplings, shrubs, and some succulent species, as well as a small proportion of grasses and xerophytic epiphytes (UNESCO 1973). We randomly located 50 plots $(10 \times 20 \mathrm{~m})$ in both chaco woodland and the forest, sampling an area of 2 ha in total. Plots with less than $80 \%$ of native vegetation coverage were excluded from the functional diversity calculations (Pakeman \& Quested 2007). In each plot, we sampled all woody individuals, including trees, shrubs, and vines with stem diameters equal to or greater than $3 \mathrm{~cm}$ at soil level and more than $1 \mathrm{~m}$ tall.

Ten soil subsamples were randomly collected in each plot at a depth of 0 to $20 \mathrm{~cm}$ to form a single composite sample per plot. We measured the macro- (phosphorus, potassium, sulfur, calcium and magnesium) and micronutrient (boron, copper, iron, zinc and manganese) content, aluminum concentration, and organic matter, following the procedures of EMBRAPA (1997).

\section{Plant functional traits}

The criteria for the collection of functional attributes followed the ecophysiological information of the nine traits: leaf area, specific leaf area, leaf succulence, leaf nitrogen concentration, leaf phosphorus concentration, average petiole length, plant height, basal area, and wood density (Cornelissen et al. 2003; Rasband 2004) (Tab. 1).

The traits were measured in the field and laboratory using up to eight individuals of each species, when possible. A branch was selected from each individual facing a northerly direction, where daylight intensity is the highest. This sample was brought to the lab and placed in water for a few hours. Then, four leaves were selected per branch, preferably older, undamaged leaves. The leaves and branches were ovendried (Cornelissen et al. 2003; Rasband 2004). For each leaf, the petiole length was measured with a digital caliper, and dried and saturated leaves were weighed on a digital scale and the leaf area of the saturated leaves obtained using ImageJ software. Wood density was measured from a piece of the branch and calculated as the ratio between the dry wood mass and its saturated volume (Pérez-Harguindeguy et al. 2013). The diameter at the base of each individual was measured with a caliper and the basal area calculated. The height of each individual was measured as the distance from the ground to the highest photosynthetic tissue.

\section{Data analyses}

We tested whether species composition differed among remnants of chaco woodland and forest with a multivariate analysis of variance based on Bray-Curtis distance matrix with 999 permutations with abundance data. The taxonomic richness was measured as the number of species in each plot and the Simpson diversity index calculated based on the log-transformed abundance (Brower \& Zar 1984; Maguran $\&$ McGill 2011). A Student's $t$-test was used to determine

Table 1. Plant traits used to calculate functional diversity and their functional relevance in woody plants in Chaco, Porto Murtinho, Mato Grosso do Sul, Brazil.

\begin{tabular}{|c|c|c|}
\hline Traits & Units & Functional relevance \\
\hline Leaf area & $\mathrm{mm}^{2}$ & $\begin{array}{l}\text { Related to leaf energy and water balance, allometric factors, } \\
\text { nutritional disorders and stress. }{ }^{1}\end{array}$ \\
\hline Specific leaf area (SLA) & $\mathrm{mm}^{2} \mathrm{mg}^{-1}$ & $\begin{array}{l}\text { Related to potential relative growth rate or } \\
\text { mass-based maximum photosynthetic rate. }{ }^{1}\end{array}$ \\
\hline Leaf nitrogen and phosphorus concentration & $\mathrm{mg} \mathrm{g}^{-1}$ & Related to the maximum photosynthetic capacity of plant growth. ${ }^{1}$ \\
\hline Leaf succulence & $\mathrm{dm}^{2}$ & Water storage capacity. ${ }^{2}$ \\
\hline Average petiole length & $\mathrm{Mm}$ & Radiation interception strategy. ${ }^{3}$ \\
\hline Stem specific density & $\mathrm{mg} \mathrm{mm} \mathrm{m}^{-3}$ & Strength and longevity, carbon storage. ${ }^{1}$ \\
\hline Plant height & M & $\begin{array}{l}\text { Competitive vigour, fecundity, growth time between disturbances; } \\
\text { rooting depth, and leaf size. }{ }^{1}\end{array}$ \\
\hline Basal area & $\mathrm{m}^{2}$ & Occupation of space by the individual; ability to acquire resources and total biomass. ${ }^{1}$ \\
\hline
\end{tabular}

${ }^{1}$ Cornelissen et al. (2003)

${ }^{2}$ Vendramini et al. (2012)

${ }^{3}$ Poorter \& Rozendaal (2008) 


\section{Environmental filters structure plant communities in the Brazilian Chaco}

any differences between remnants. Soil variables were logtransformed before performing parametric analyses to meet normal distribution assumptions. A Principal Component Analysis (PCA) was used to visualize the relationships between soil nutrients and the plots of each remnant, as well as the distribution of community weighted mean of traits between both remnants. All analyses were performed in the R environment (R Development Core Team 2017). The dominance of species was measured with their abundance in each sampling area.

The community-level weighted mean (CWM) of each trait was taken as the average value of the trait for all species in a plot, weighted by the species abundance. The calculation of functional diversity followed the method proposed by Mason et al. (2013), separating functional diversity into two components. First, functional richness (Villéger et al. 2008) and functional dispersion (Laliberte \& Legendre 2010) were calculated. Then, the standardized effect size of functional richness (SESFRic) relative to random expectation was estimated under a matrix-swap null model and standardized effect size for functional dispersion (SESFDis) relative to values obtained when abundances were randomized across species while within plots. These two indices represent the two components affected by diversity assembly rules: richness and abundance. These indices are not affected by variation in species richness along an environmental gradient or change in functional richness, respectively; see more details in Mason et al. (2013). In addition, it was possible to detect changes in the community or a gradient when the priority effect (with SESFRic) or mass effect (with SESFDis) had a strong influence on species occurrence (Mason et al. 2013). We used the Wilcoxon rank-sum to test for differences in these indices between remnants.

\section{Results}

We sampled 1381 individuals in chaco woodland and 2970 in chaco forest, from 26 species in woodland and 66 in the forest. Of these, 49 species were exclusive to the forest and only nine to woodland. Both remnants shared a total of 17 species, with an overall total of 75 species (Tab. 2).

Table 2. List of families, species, and abundance of individuals sampled in chaco woodland and forest in Porto Murtinho, Mato Grosso do Sul, Brazil.

\begin{tabular}{|c|c|c|c|}
\hline Family & Species & Woodland & Forest \\
\hline Anacardiaceae & Astronium urundeuva (M. Allemão) Engl. & 0 & 21 \\
\hline \multirow{2}{*}{ Annonaceae } & Annona emarginata (Schltdl.) H.Rainer & 0 & 9 \\
\hline & Annona nutans (R.E.Fr.) R.E.Fr. & 8 & 0 \\
\hline \multirow{2}{*}{ Apocynaceae } & Aspidosperma quebracho-blanco Schltdl. & 11 & 0 \\
\hline & Forsteronia sp. & 0 & 3 \\
\hline \multirow{4}{*}{ Bignoniaceae } & Bignonia corymbosa (Vent.) L.G.Lohmann & 0 & 81 \\
\hline & Fridericia sp & 0 & 20 \\
\hline & Handroanthus heptaphyllus (Vell.) Mattos & 1 & 10 \\
\hline & Tabebuia nodosa (Griseb.) Griseb. & 3 & 107 \\
\hline Cannabaceae & Celtis iguanaea (Jacq.) Sarg. & 4 & 84 \\
\hline \multirow{2}{*}{ Capparaceae } & Anisocapparis speciosa (Griseb.) Cornejo \& Iltis & 0 & 13 \\
\hline & Cynophalla retusa (Griseb.) Cornejo \& Iltis & 18 & 89 \\
\hline Combretaceae & Combretum leprosum Mart. & 6 & 5 \\
\hline \multirow{5}{*}{ Euphorbiaceae } & Adelia membranifolia (Müll.Arg.) Chodat \& Hassl. & 0 & 226 \\
\hline & Gymnanthes discolor (Spreng.) Müll.Arg. & 0 & 1229 \\
\hline & Jatropha ribifolia (Pohl) Baill. & 97 & 0 \\
\hline & Sapium haematospermum Müll.Arg. & 1 & 81 \\
\hline & Sebastiania brasiliensis Spreng. & 0 & 24 \\
\hline \multirow{14}{*}{ Fabaceae } & Albizia inundata (Mart.) Barneby \& J.W.Grimes & 0 & 1 \\
\hline & Anadenanthera colubrina (Vell.) Brenan & 0 & 5 \\
\hline & Bauhinia hagenbeckii Harms & 1 & 0 \\
\hline & Enterolobium contortisiliquum (Vell.) Morong & 1 & 2 \\
\hline & Libidibia paraguariensis (D. Parodi) G.P. Lewis & 0 & 9 \\
\hline & Machaerium eriocarpum Benth. & 10 & 0 \\
\hline & Microlobius foetidus (Jacq.) M.Sousa \& G.Andrade & 0 & 9 \\
\hline & Mimosa hexandra Micheli & 156 & 8 \\
\hline & Muellera nudiflora (Burkart) M.J. Silva \& A.M.G. Azevedo & 0 & 9 \\
\hline & Parapiptadenia rigida (Benth.) Brenan & 0 & 1 \\
\hline & Parkinsonia praecox (Ruiz \& Pav.) Hawkins & 305 & 0 \\
\hline & Piptadenia viridiflora (Kunth) Benth. & 0 & 1 \\
\hline & Prosopis rubriflora Hassler. & 468 & 20 \\
\hline & Pterogyne nitens Tul. & 0 & 1 \\
\hline
\end{tabular}


Vivian Almeida Assunção, Danilo Muniz da Silva, Guilherme Dalponti, Ângela Lúcia Bagnatori Sartori, José Carlos Casagrande and Vidal de Freitas Mansano

Table 2. Cont.

\begin{tabular}{|c|c|c|c|}
\hline Family & Species & Woodland & Forest \\
\hline \multirow{7}{*}{ Malvaceae } & Byttneria rhamnifolia Benth. & 0 & 1 \\
\hline & Ceiba samauma (Mart.) K.Schum. & 0 & 4 \\
\hline & Ceiba speciosa (A.St.-Hil.) Ravenna & 0 & 2 \\
\hline & Eriotheca sp. & 0 & 1 \\
\hline & Guazuma ulmifolia Lam. & 0 & 24 \\
\hline & Helicteres brevispira A.St.-Hil. & 0 & 1 \\
\hline & Sidastrum micranthum (A.St.-Hil.) Fryxell & 0 & 16 \\
\hline \multirow{2}{*}{ Meliaceae } & Trichilia catigua A.Juss. & 0 & 20 \\
\hline & Trichilia elegans A.Juss. & 0 & 20 \\
\hline \multirow{3}{*}{ Moraceae } & Maclura sp. & 0 & 2 \\
\hline & Maclura tinctoria (L.) D.Don ex Steud. & 0 & 7 \\
\hline & Sorocea sp. & 1 & 16 \\
\hline \multirow{2}{*}{ Myrtaceae } & Eugenia subterminalis DC & 4 & 35 \\
\hline & Psidium guajava L. & 0 & 5 \\
\hline \multirow{4}{*}{ Nyctaginaceae } & Guapira sp. & 0 & 26 \\
\hline & Neea hermaphrodita S. Moore & 0 & 52 \\
\hline & Pisonia zapallo Griseb. & 0 & 1 \\
\hline & Reichenbachia hirsuta Spreng. & 0 & 34 \\
\hline Opiliaceae & Agonandra brasiliensis Miers ex Benth. \& Hook.f. & 0 & 9 \\
\hline \multirow{6}{*}{ Polygonaceae } & Coccoloba cordata Cham. & 0 & 5 \\
\hline & Coccoloba paraguariensis Lindau & 3 & 18 \\
\hline & Coccoloba rigida Meisn. & 6 & 129 \\
\hline & Ruprechtia exploratricis Sandwith & 6 & 67 \\
\hline & Salta triflora (Griseb.) Adr. Sanchez & 0 & 7 \\
\hline & Securidaca sp. & 0 & 1 \\
\hline Rhamnaceae & Sarcomphalus mistol (Griseb.) Hauenschild & 168 & 0 \\
\hline \multirow{4}{*}{ Rubiaceae } & Calycophyllum multiflorum Griseb. & 0 & 18 \\
\hline & Chomelia obtusa Cham. \& Schltdl. & 8 & 142 \\
\hline & $\begin{array}{c}\text { Machaonia brasiliensis (Hoffmanss. ex Humb.) } \\
\text { Cham. \& Schltdl. }\end{array}$ & 0 & 47 \\
\hline & Randia armata (Sw.) DC. & 9 & 15 \\
\hline \multirow{2}{*}{ Rutaceae } & Zanthoxylum fagara (L.) Sarg. & 0 & 20 \\
\hline & Zanthoxylum monogynum A. St.-Hil. & 1 & 0 \\
\hline \multirow{5}{*}{ Salicaceae } & Casearia aculeata Jacq. & 0 & 3 \\
\hline & Casearia gossypiosperma Briq. & 0 & 1 \\
\hline & Casearia sp. & 0 & 3 \\
\hline & Laetia americana $\mathrm{L}$. & 0 & 27 \\
\hline & Prockia crucis P.Browne ex L. & 0 & 5 \\
\hline \multirow{3}{*}{ Sapindaceae } & Allophylus edulis (A.St.-Hil. et al.) Hieron. ex Niederl. & 0 & 9 \\
\hline & Diplokeleba floribunda N.E.Br. & 0 & 20 \\
\hline & Paullinia pinnata L. & 1 & 87 \\
\hline Sapotaceae & Pouteria sp. & 0 & 1 \\
\hline Simaroubaceae & Castela coccinea Griseb. & 84 & 0 \\
\hline Ulmaceae & Phyllostylon rhamnoides (Poiss.) Taub. & 0 & 1 \\
\hline
\end{tabular}

Species composition differed between remnants $(t=$ $45.9, \mathrm{P}=0.001)$. Chaco forest had the highest number of individuals $(\mathrm{t}=10.2, \mathrm{P}<0.001)$, richness $(\mathrm{t}=8.8, \mathrm{P}<0.001)$, and Simpson's diversity $(t=5.01, P<0.001)$ (Fig. 1 ).

The PCA diagram of soil variables separated the plots by remnants (Fig. 2). The eigenvalues of axes one and two were 5.09 and 1.55 , respectively, which cumulatively explained $53 \%$ of the variation. Chaco forest had higher nutrient contents, and chaco woodland had higher levels of trace elements sulfur (S) and aluminum (Al) (Fig. 2).
The PCA of the community weighted mean of traits also separated the two remnants, with a cumulative variation of the two axes being $70.16 \%$ and eigenvalues of axes one and two being 3.52 and 2.79 , respectively (Fig. 3). The highest values for succulence and foliar nitrogen were found in chaco woodland, while height, leaf area, and specific leaf area were higher in chaco forest (Figs. 3, 4). Axis two was related to leaf phosphorus, petiole length, and specific stem density, which did not separate the remnants but did indicate variation within them (Figs. 3, 4). 

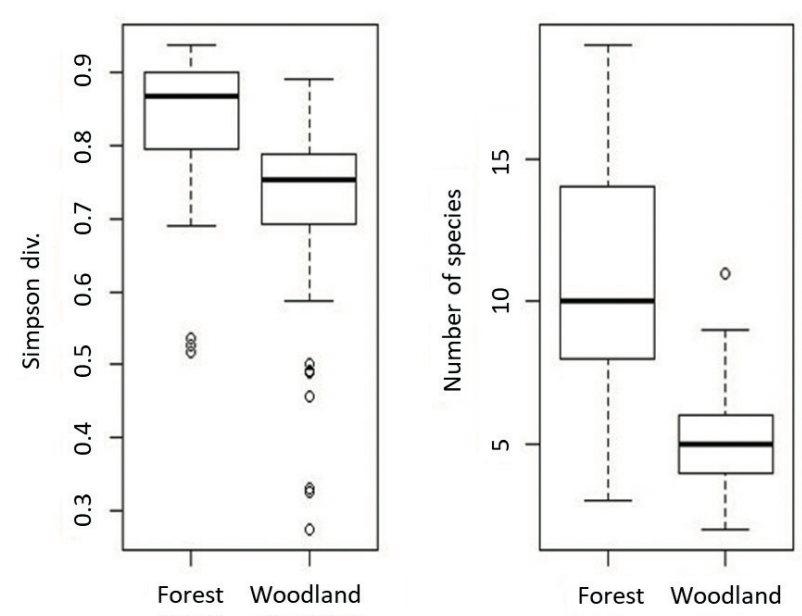

Figure 1. Simpson Diversity and number of species in chaco forest and chaco woodland in Porto Murtinho, Mato Grosso do Sul, Brazil.

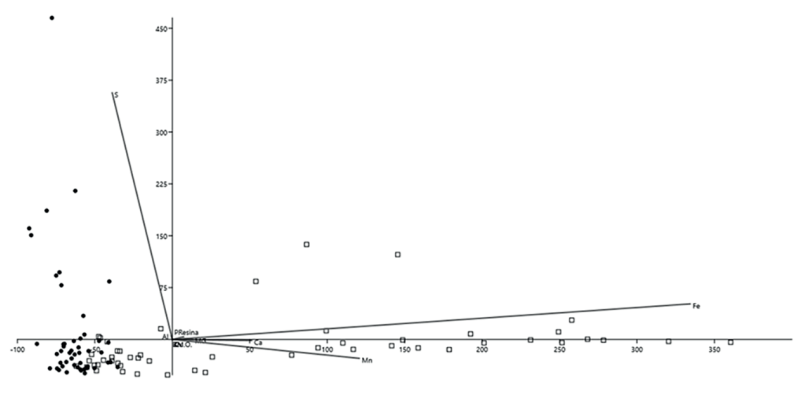

Figure 2. Ordination through Principal Component Analysis (PCA) of the soil nutrients in two remnants of the Chaco, Porto Murtinho, Mato Grosso do Sul, Brazil. The percentage of cumulative variance explained by the two axes is $55.3 \%$. (P. Resin = phosphorus, $\mathrm{O} . \mathrm{M} .=$ organic matter, $\mathrm{K}=$ potassium, $\mathrm{Ca}=$ calcium, $\mathrm{Mg}=$ magnesium, $\mathrm{Al}=$ aluminum, $\mathrm{S}=$ sulfur, $\mathrm{B}=$ boron, $\mathrm{Cu}=$ copper, $\mathrm{Fe}=$ iron, $\mathrm{Zn}=$ zinc, $\mathrm{Mn}=$ manganese, square = chaco forest, circle $=$ chaco woodland).

The standardized effect size of functional richness (SESFRic) differed among remnants ( $\mathrm{W}=1419, \mathrm{P}=$ 0.002); however, the standardized effect size of functional dispersion (SESFDis) did not differ $(\mathrm{W}=1340, \mathrm{P}=0.239)$ (Fig. 5, Tab. S1 in supplementary material).

\section{Discussion}

We found abundant and exclusive species in both remnants. However, a high number of exclusive species, ca. $74 \%$, occurred in chaco forest. In addition, species common in chaco woodland, such as Prosopis rubriflora, Parkinsonia praecox, Sarcomphalus mistol and Mimosa hexandra (Nunes 2006; Sartori 2012; Lima 2012), were exclusive to the chaco woodland plot, suggesting that a filter could be selecting the species that occur in chaco woodland.

A low variation in soil fertility and elemental composition among the different types of Chaco (Morello 1967) might act as an environmental filter for woody species, driving community composition and structure at a local scale. Previous studies have considered the soil as a determinant of variation in phytophysiognomies in the Cerrado (Gottsberger \& Silberbauer-Gottsberger 2006; Almeida et al. 2018; Barros et al. 2018), Amazonian Caatinga (Coomes \& Grubb 1996), Mata Atlântica (Nettesheim et al. 2019; Arruda et al. 2020), Argentinean Chaco (Kunst et al. 2006) and Paraguayan Chaco (Navarro et al. 2006).

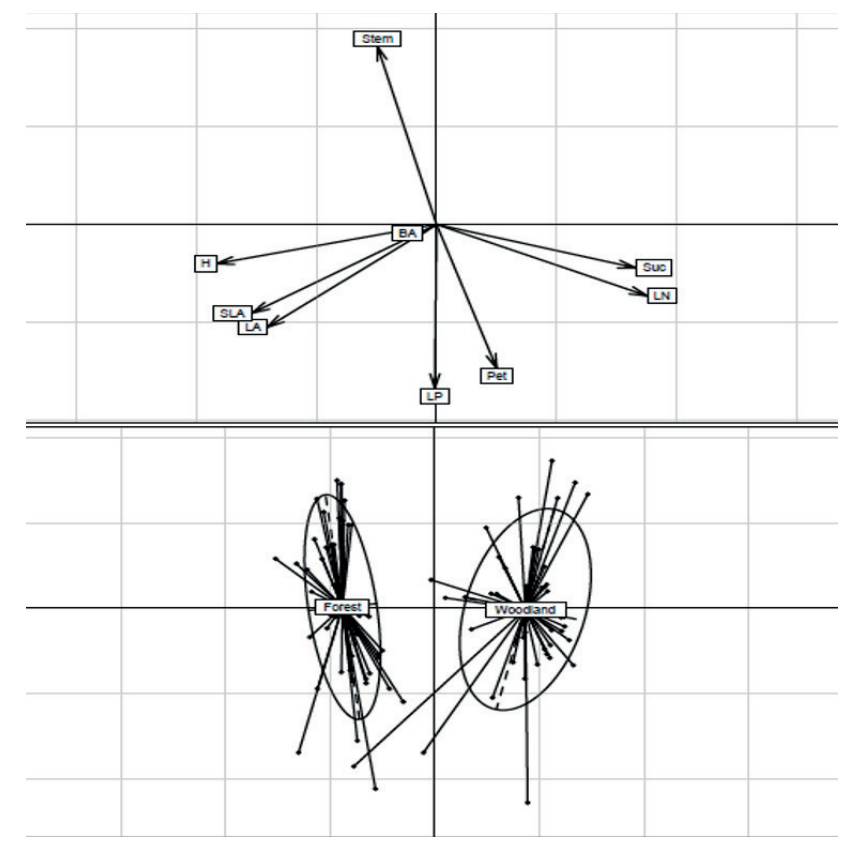

Figure 3. Ordination through Principal Component Analysis (PCA) of the community-level weighted mean (CWM) of the traits in two Chaco remnants, Porto Murtinho, Mato Grosso do Sul, Brazil. The percentage of cumulative variance explained by the two axes is $70.16 \%$. (LA = leaf area, SLA = specific leaf area, Suc = leaf succulence, $\mathrm{LN}=$ leaf nitrogen concentration, $\mathrm{LF}=$ leaf phosphorus concentration average, $\mathrm{Pet}=$ petiole length, $\mathrm{H}=$ plant height, BA = basal area, Stem = wood density, Forest= chaco forest, Woodland $=$ chaco woodland).

The number of individuals of trees and shrubs in chaco forest is more than twice that of the chaco woodland. This aspect can be observed in the formation of denser, closed forest, with canopy and undergrowth, which can be related to a positive feedback system in which nutrient availability in the soil increases organic matter (Lambers et al. 2008) further enriching the soil, thus supporting even denser vegetation and higher biomass (Aerts 1999; Leigh Jr et al. 2004; Suding et al. 2004; Miatto \& Batalha 2018). In these situations, the increasing canopy density forces competition for light. Competition for luminosity has been considered as an important driver of the vegetational structure of the Chaco (Kunst et al. 2006). This aspect is supported in this study for the chaco forest.

Leaves with smaller areas and higher nitrogen concentration were reported for the chaco woodland. These 

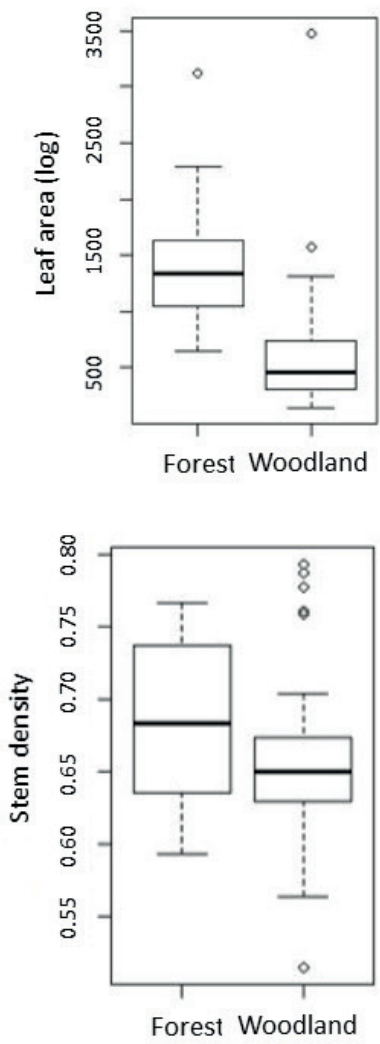
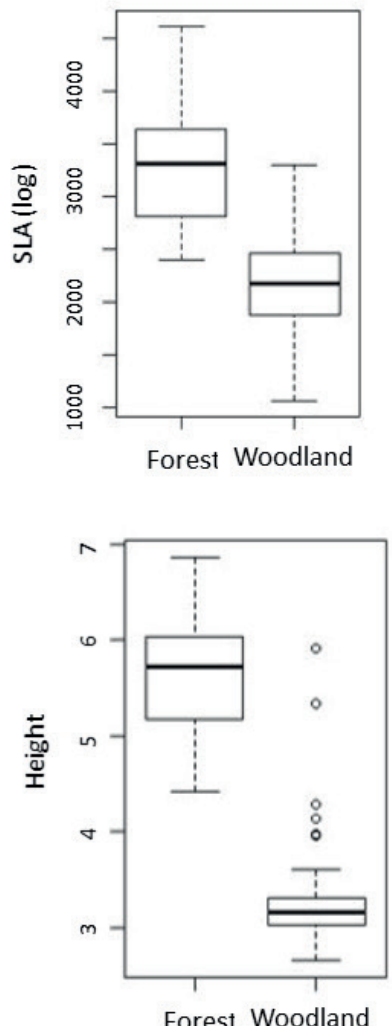
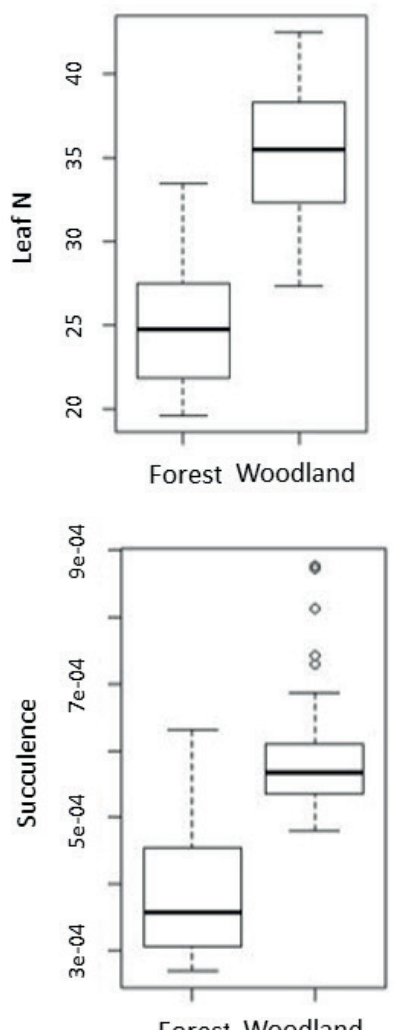
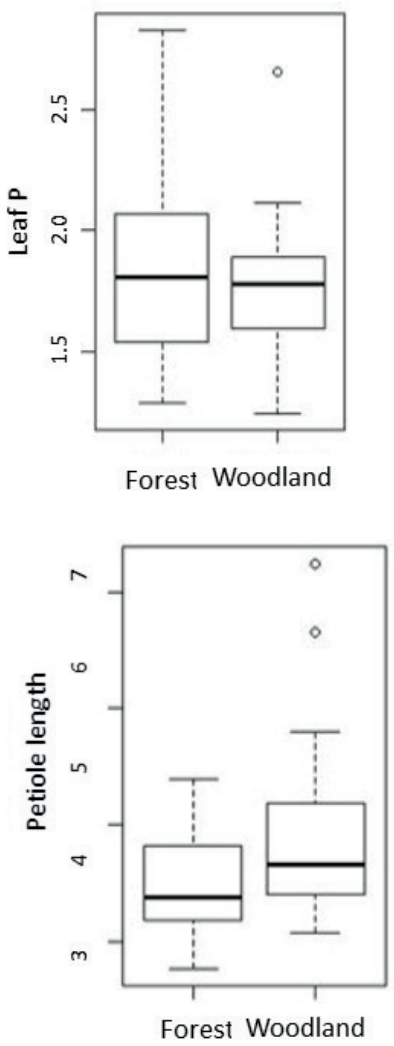

Figure 4. Community-level weighted mean (CWM) of each trait in chaco forest and chaco woodland in Porto Murtinho, Mato Grosso do Sul, Brazil. (SLA = specific leaf area, Leaf $\mathrm{N}$ = leaf nitrogen, Leaf $\mathrm{P}=$ leaf phosphorus).

attributes were indicated as an adaptation to nutritional stress i.e., lower values of macro- and micronutrients in the soil (Coomes \& Grubb 2000; Vendramini et al. 2002; Cornelissen et al. 2003, Miatto \& Batalha 2018). In addition, higher leaf succulence results from the need for water storage because of high solar radiation related to the open canopy (Vendramini et al. 2002; Cornelissen et al. 2003; IBGE 2012). Although the climatic conditions are similar for both remnants, the vegetation structure alters the local microclimate (Moles et al. 2014; Gerhold et al. 2015; Miatto \& Batalha 2018), leading to drier conditions in chaco woodland. Conversely, in chaco forest, the prevailing attributes indicate competition for light; trees presented higher leaf area or higher specific leaf area, hence larger surface for light absorption, leading to higher potential growth rate with a corresponding increase in size (PérezHarguindeguy et al. 2013). Accordingly, the woody species of chaco forest were taller and, thus, able to intercept light in the upper strata, leading to the low representation of understory plants in the chaco forest (Vendramini et al. 2002; Leps et al. 2011). Niche partitioning becomes important for species co-occurrence because competition for light increases once species are released from competition for soil nutrients (Coomes \& Grubb 2000; Mouchet et al. 2010; Mason et al. 2011; 2013). Thus, in chaco forest, species are selected for different traits that allow them to co-occur.
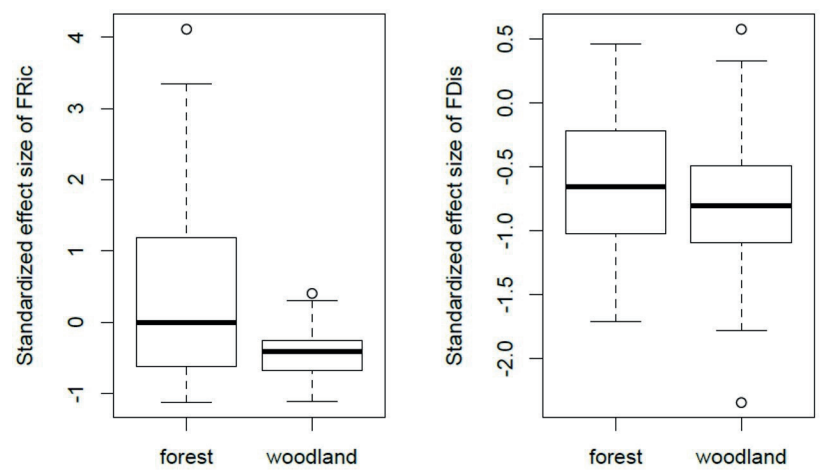

Figure 5. Standardized effect size of functional richness and functional dispersion in chaco forest and chaco woodland in Porto Murtinho, Mato Grosso do Sul, Brazil.

The soil filter decreased from woodland to chaco forest. According to Mason et al. (2013), the niche complementarity influences the occurrence of species but not their abundances based on a change in SESFRic but not in SESFDis. The similar SESFDis indicates that the complementary niche is important for the occurrence of species but does not affect the abundance (Mason et al. 2013). The richer soils of chaco forest supported exclusive species and the co-occurrence of functionally different species, e.g., species with high leaf area, such as Ceiba samauma, and species with low leaf 


\section{Environmental filters structure plant communities in the Brazilian Chaco}

area but with high specific leaf area, such as Sebastiania brasiliensis. On the other hand, in chaco woodland even the richer soil and denser plots presented functionally similar species, such as Aspidosperma quebracho-blanco, Mimosa hexandra, Parkinsonia praecox, Prosopis rubriflora and Sarcomphalus mistol, further supporting the idea that poor soils act as an environmental filter that reduces functional diversity. Consequently, woodland and chaco forest were not just functionally different in their attributes but also in their functional richness, which was reduced in chaco woodland by environmental filters but higher in chaco forest because of probable competition for light.

With the obtained data we observed that there is a diversity gradient in the Brazilian Chaco, as described by Whittaker (1967), presumably related to soil fertility. The occurrence of fewer species and less diversity in woodland environments is likely a result of nutrient-poorer soil in this area. These differences in floristic composition and soil fertility were reflected in species traits, which were responsive to poorer soils in chaco woodland, whereas adaptation to competition for light is probably the main driver of community assembly in chaco forest. Thus, an environmental filter hinders species establishment in chaco woodland, while the probable competition for light is possibly the main driver of functional diversity in the forest.

\section{Acknowledgements}

We are grateful to CAPES and CNPq (process 140504/2015-0) for the scholarship to VAA, to CAPES for the scholarship ALBS, VFM (processes 309987/2012-1 and 308047/2013-3) and to DMS. To the Casadinho Project PROCAD (552352/2011-0). We acknowledge the scientists for plant identification: A.Lobão, A.Pott, C.FdeSá, M.daC. Souza, F.M.Alves, T.R.F.Sinani, R. Marquete and M.Bovini. We thank also the staff and owners of the "Retiro Conceição" and "Santa Virgínia" ranches.

\section{References}

Adamoli J, Sennhauser E, Acero JM, Rescia A. 1990. Stress and disturbance: vegetation dynamics in the dry Chaco region of Argentina. Journal of Biogeography 17: 491-500.

Aerts R. 1999. Interespecific competition in natural plant communities: mechanisms, trade-offs and plan-soil feedbacks. Journal of Experimental Botany 330: 29-37.

Almeida HA, Bahia TO, Gélvez-Zúñiga I, Fernandes GW. 2018. Together yet separate: variation in soil chemistry determines differences in the arboreal-shrub structure of two contiguous rupestrian environments. Acta Botanica Brasilica 32: 578-587.

Arruda DM, Magnago LFS, Solar RRC, et al. 2020. Soil and climate equally contribute to changes in the species compositions of Brazilian dry forests across $300 \mathrm{~km}$. Journal of Plant Ecology 13: 171-176.

Barros MF, Pinho BX, Leão T, Tabarelli M. 2018. Soil attributes structure plant assemblages across an Atlantic forest mosaic. Journal of Plant Ecology 11: 613-622.
Bertness MD, Callaway R. 1994. Positive interactions in communities. Trends in Ecology \& Evolution 9: 191-193.

BRASIL. 1982. Ministério das Minas e Energia. Departamento Nacional de Produção Mineral. Projeto RADAMBRASIL: Folha SF.21 - Campo Grande; geologia, geomorfologia, pedologia, vegetação e uso potencial da terra. Rio de Janeiro, Brasil, RADAMBRASIL.

Brower JE, Zar JH. 1984. Field \& laboratory methods for general ecology. Dubuque, Iowa, William C. Brown Company Publishers.

Carvalho FS, Sartori ALB. 2014. Reproductive phenology and seed dispersal syndromes of woody species in the Brazilian Chaco. Journal of Vegetation Science 26: 302-311.

Connor EF, Simberloff D. 1979. The assembly of Species Communities: Chance or Competition? Ecology 60: 1132-1140.

Coomes DA, Grubb PJ. 1996. Amazonian caatinga and related communities at La Esmeralda. Venezuela: forest structure, physiognomy and floristics, and control by soil factors. Vegetatio 122: 167-191.

Coomes DA, Grubb PJ. 2000. Impacts of Root Competition in Forests and Woodlands: A Theoretical Framework and Review of Experiments. Ecological Monographs 70: 171-207.

Cornelissen JHC, Lavorel S, Garnier E, at al. 2003. A handbook of protocols for standardised and easy measurement of plant functional traits worldwide. Australian Journal of Botany 51: 335-380.

Diamond JM. 1975. Assembly of Species Communities. In: Diamond JM, Cody ML. (eds.) Boston: ecology and evolution of communities. Boston, Harvard University Press. p. 342-344.

Dwyer JM, Laughlin DC. 2017. Selection on trait combinations along environmental gradients. Journal of Vegetation Science 28: 672-673.

EMBRAPA - Empresa Brasileira de Pesquisa Agropecuária. 1997. Centro Nacional de Pesquisa de Solos. Manual de métodos de análise de solo / Centro Nacional de Pesquisa de Solos. Rio de Janeiro, EMBRAPACNPS. https://www.agencia.cnptia.embrapa.br/Repositorio/Manual +de+Metodos_000fzvhotqk02wx5ok0q43a0ram31wtr.pdf.

Gerhold P, Cahill JR JF, Winter M, Bartish IV, Prinzing A. 2015. Phylogenetic patterns are not proxies of community assembly mechanisms (they are far better). Functional Ecology 29: 600-614.

Gottsberger G, Silberbauer-Gottsberger I. 2006. Life in the cerrado: a South American tropical seasonal vegetation. Vol. 1. Origin, structure, dynamics and plant use. Cambridge, Reta Verlag.

Gurevitch J, Scheiner SM, Fox GA. 2009. Ecologia Vegetal. Porto Alegre, Artmed.

Hueck K. 1972. As regiões de matas do Chaco e áreas marginais. In: Azevedo JCA, Anjos CV, Gomes LC, et al. (eds.) As florestas da América do Sul: ecologia, composição e importância econômica, Distrito Federal, BR, Editora Polígono. p. 240-275.

IBGE - Instituto Brasileiro de Geografia e Estatística. 2012. Manual técnico da vegetação brasileira: sistema fitogeográfico, inventário das formações florestais e campestres, técnicas e manejo de coleções botânicas, procedimentos para mapeamentos. Rio de Janeiro, IBGE. https://biblioteca.ibge.gov.br/visualizacao/livros/liv63011.pdf.

Köppen W. 1948. Climatologia. Fundo de Cultura Económica. México, Fondo de Cultura Económica.

Kraft NJB, Adler PB, Godoy O, James EC, Fuller S, Levine JM. 2014. Community assembly, coexistence and the environmental filtering metaphor. Functional Ecology 29: 592-599.

Kunst C, Monti E, Pérez H, Godoy J. 2006. Assessment of the rangelands of southwestern Santiago del Estero, Argentina, for grazing management and research. Journal of Environmental Management 80: 248-265.

Laliberte E, Legendre P. 2010. A distance-based framework for measuring functional diversity from multiple traits. Ecology. 91: 299-305.

Lambers H, Stuart Chapin III F, Pons TL. 2008. Plant Physiological Ecology. New York, Springer-Verlag.

Leibold M. 1998. Similarity and local coexistence of species in regional biotas. Evolutionary Ecology 12: 95-100

Leibold MA. 2008. Return of the niche. Nature 454: 39-41.

Leigh Jr EG, Davidar P, Dick CW, Puyravaud J P, Terborgh J, Steege H Ter, Wright SJ. 2004. Why Do Some Tropical Forests Have So Many Species of Trees? Biotropica 36: 447-473.

Leps J, Bello F, Smilauer P, Dolezal J. 2011. Community trait response to environment: disentangling species turnover vs intraspecific trait variability effects. Ecography 34: 856-863. 


\section{Vivian Almeida Assunção, Danilo Muniz da Silva, Guilherme Dalponti, Ângela Lúcia Bagnatori Sartori, José Carlos Casagrande and Vidal de Freitas Mansano}

Lewis JP, Pire EE, Prado DE, Stofella SL, Franceschi EA, Carnevale NJ. 1990. Plant communities and phytogeographical position of a large depression in the Great Chaco, Argentina. Vegetatio 86: 25-38.

Lima TE. 2012. Perturbação ambiental em remanescentes de chaco e mecanismos de defesa em leguminosas. MSc Thesis, Universidade Federal de Mato Grosso do Sul, Campo Grande.

Loreau M. 2000. Biodiversity and ecosystem functioning: recent theoretical advances. Oikos 91: 3-17.

Maguran AE, Mcgill BJ. 2011 Biological diversity frontiers in measurement and assessment. United Kingdom, Oxford University Press.

Mason NWH, Bello F, Dolezal J, Leps J. 2011. Niche overlap reveals the effects of competition, disturbance and contrasting assembly processes in experimental grassland communities. Journal of Ecology 99: 788796.

Mason NWH, Bello FD, Mouillot D, Pavoine S, Stéphane D. 2013. A guide for using functional diversity indices to reveal changes in assembly processes along ecological gradients. Journal of Vegetation Science 24: 794-806.

Miatto RC, Batalha MA. 2018. Are the cerrado and the seasonal forest woody floras assembled by different processes despite their spatial proximity? Journal of Plant Ecology 11: 740-750.

Moles DAT, Shawn SEP, Laffan W, et al. 2014. Which is a better predictor of plant traits: temperature or precipitation? Journal of Vegetation Science 25: 1167-1180.

Morales M, Oakley L, Sartori ALB, et al. 2019. Diversity and conservation of legumes in the Gran Chaco and biogeograpical inferences. PLOS ONE 14: e0220151. doi: 10.1371/journal.pone.0220151

Morello J. 1967. Bases para el estudio fitoecológico de los grandes espacios (el Chaco argentino). Ciencia y Investigación Agraria 23: 252-267.

Mouchet MA, Villéger S, Mason NWH, Mouillot D. 2010. Functional diversity measures: an overview of their redundancy and their ability to discriminate community assembly rules. Functional Ecology 24: 867-876.

Navarro G, Molina JA, Molas LP. 2006. Classification of the forests of the northern Paraguayan Chaco. Phytoecologia 36: 473-508.

Nettesheim FC, Garbin ML, Pereira MG, Araujo DSD. 2019. Local environmental controls of Atlantic Forest tree Community assembly on a coastal continental island in southeastern Brazil. Acta Botanica Brasilica 33: 88-96.

Nunes GP. 2006. Estudo florístico de formações chaquenhas brasileiras e caracterização estrutural de um remanescente de Chaco de Porto Murtinho, MS, Brasil. MSc. Thesis, Universidade Federal de Mato Grosso do Sul, Campo Grande.

Oliveira-Filho AT, Jarenkow JA, Rodal MJN. 2006. Floristic relationships of seasonally dry forests of eastern South America based on tree species distribution patterns. In: Pennington RB, Lewis GP, Ratter JA. (eds.) Neotropical savannas and dry forests: Plant diversity, biogeography and conservation. New York, Boca Raton, Taylor \& Francis CRC Press. p. 151-184.
Padilha DRC. 2011. Fitossociologia e estimativas da biomassa aérea e de carbono em chaco florestado no Brasil. MSc. Thesis, Universidade Federal de Mato Grosso do Sul, Campo Grande.

Pakeman RJ, Quested HM. 2007. Sampling plant functional traits: What proportion of the species need to be measured? Applied Vegetation Science 10: 91-96.

Pausas JG, Verdú M. 2008. Fire reduces morphospace occupation in plant communities. Ecology 89: 2181-2186.

Pérez-Harguindeguy N, Díaz S, Garnier E, et al. 2013. New handbook for standardised measurement of plant functional traits worldwide. Australian Journal of Botany 61: 167-234.

Pinho BX, Tabarelli B, Engelbrecht BMJ, Sfaird J, Melo FPL. 2019. Plant functional assembly is mediated by rainfall and soil conditions in a seasonally dry tropical forest. Basic and Applied Ecology 40: 1-11.

Poorter L, Rozendaal DMA. 2008. Leaf size and leaf display of thirty-eight tropical tree species. Oecologia 158: 35-46.

Prado DE. 1993. What is the Gran Chaco vegetation in South America? I A review. Contribution to the study of the flora and vegetation of the chaco. V. Candollea 48: 145-172.

R Development Core Team. 2017. R: A language and environment for statistical computing. Vienna, Austria, R Foundation for Statistical Computing. https://www.r-project.org/. 16 Feb. 2017.

Ramella R, Spichiger R. 1989 Interpretación preliminar del medio físico y de la vegetación del Chaco boreal. Contribución al estudio de la flora y de la vegetación del Chaco. Candollea 44: 639-680.

Rasband W. 2004. ImageJ: Image process and analysis in Java. Bethesda, National Institute of Health.

Sartori ALB. 2012. The Brazilian Chaco. GLALIA: Revista Electrónica del Grupo Latinoamericano de Liquenólogos 4: 11-18.

Schluter D. 2000. Ecological Character Displacement in Adaptive Radiation. The American Naturalist 156: 4-16.

Suding KN, Gross KL, Houseman G R. 2004. Alternative states and positive feedbacks in restoration ecology. Trends in Ecology \& Evolution 19: 46-53.

Tang J, Zhou S. 2011. The importance of niche differentiation for coexistence on large scales. Journal of Theoretical Biology 273: 32-36.

Townsend CR, Begon M, Harper JL. 2006. Fundamentos de ecologia. Porto Alegre, Artmed.

UNESCO 1973. International classification and mapping of vegetation. London, UNESCO.

Vellend M. 2010. Conceptual Synthesis in Community Ecology. The Quarterly Review of Biology 85: 183-206.

Vendramini F, Díaz S, Gurvich DE, Wilson PJ, Thompson K, Hodgson JG 2002. Leaf traits as indicators of resource-use strategy in floras with succulent species. New Phytologist 154: 147-157.

Villéger S, Mason NWH, Mouillot D. 2008. New Multidimensional Functional Diversity Indices for a Multifaceted Framework in Functional Ecology. Ecology 89: 2290-2301.

Whittaker RH. 1967 Gradient Analysis of Vegetation. Biological Reviews 49: $207-264$ 